\title{
Real Time RT-PCR with a Newly Designed Set of Primers Confirmed the Presence of $2 b$ and $2 x / d$ Myosin Heavy Chain mRNAs in the Rat Slow Soleus Muscle
}

\author{
J. ŽURMANOVÁ ${ }^{1,2}$, F. PŮTA ${ }^{2}$, R. STOPKOVÁ ${ }^{2}$, T. SOUKUP ${ }^{1}$ \\ ${ }^{1}$ Institute of Physiology, AS ČR, Prague, ${ }^{2}$ Faculty of Science, Charles University in Prague, Prague, \\ Czech Republic
}

Received September 4, 2008

Accepted November 28, 2008

\begin{abstract}
Summary
In order to re-evaluate the presence and relative quantity of $2 \mathrm{~b}$ and $2 x / d$ myosin heavy chain $(\mathrm{MyHC})$ transcripts in rat slow soleus muscle by using real time RT-PCR we have compared the available relevant $C D N A$ sequences and designed a new set of primers having similar melting temperatures, matching separate $\mathrm{MyHC}$ exons in the regions of maximal differences in MyHC coding sequences, and containing $\mathrm{G}$ or $\mathrm{C}$ at the $3^{\prime}$-end. These also yielded PCR products of corresponding length, which is an important requirement for real time RT-PCR quantification. The experiments were performed on 8-month-old inbred female Lewis strain rats used in our current study of regenerating transplanted muscles. The real time RT-PCR measurement confirmed the expression of all four MyHC mRNAs (type 1, 2a, 2x/d and 2b) in both fast extensor digitorum longus and slow soleus muscles, although in the soleus muscle of adult rats, only type 1 and $2 a$ protein isoforms can be usually detected.
\end{abstract}

\section{Key words}

Rat slow soleus muscle • Rat fast EDL muscle • Myosin heavy chain isoforms • Real time RT-PCR

\section{Corresponding author}

T. Soukup, Institute of Physiology, Czech Academy of Sciences, Vídeňská 1083, CZ-142 20 Prague, Czech Republic. Fax: +420 224752 488. E-mail: tsoukup@biomed.cas.cz

\section{Introduction}

Myosin heavy chain (MyHC) $c D N A$ sequences are highly conserved among mammals including human, mouse and rat. Although the full sequence of human and mouse type 1, 2a, 2x/d and 2b MyHC isoforms has been described, the information for rat is still incomplete and often controversial, especially for the $2 \mathrm{~b}$ isoform. MyHC isoform $m R N A$ levels in different muscles and in various species have often been analyzed by reverse transcription followed by polymerase chain reaction (RT-PCR) (Lieber et al. 1993, Ennion et al. 1995, Peuker and Pette 1995, 1997, Jänkälä et al. 1997, Wright et al. 1997, Jaschinski et al. 1998, Jung et al. 1998, Stevens et al. 1999, Sakuraba et al. 2005, for review see Schiaffino and Reggiani 1996). The RT-PCR proved to be a powerful and sensitive method to determine even a small amount of $m R N A$. Despite many modifications it was, however, difficult to obtain the quantitative data, apparently due to the exponential nature of the PCR. At present, the real time RT-PCR approach is required in order to receive quantitative data of respective transcripts. Regarding MyHC isoform $m R N A s$, the primers used previously in the above studies were inconsistent in their melting temperatures and length of PCR products, which would complicate the experimental design of the real time RTPCR. They also did not always match separate exons or the sequences with maximal variability, which is required for high specificity RT-PCR measurement.

The soleus is a slow antigravity muscle designated to sustained prolonged activity, consisting in adult rats of a great majority of slow type 1 fibers supplemented by a small number of fast $2 \mathrm{~A}$ fibers containing type 1 and $2 \mathrm{a}$ MyHC isoforms, respectively. The EDL muscle, on the other hand, is a typical fast 


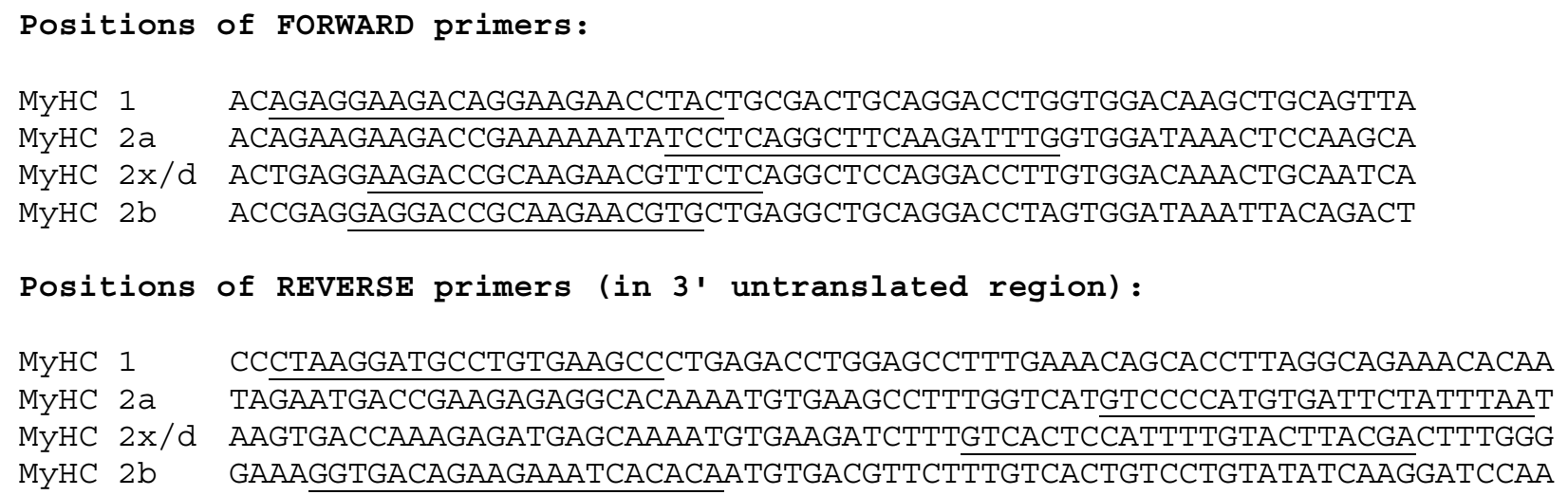

Fig. 1. Primers positions. Positions of primers used for MyHC-isoform mRNAs RT-PCR quantification are underlined. The reverse prime sequences are reversely complement to respective underlined ones.

contracting muscle involved in intermittent bursting efforts and it is composed from type $1,2 \mathrm{~A}, 2 \mathrm{X} / \mathrm{D}$ and $2 \mathrm{~B}$ fibers containing corresponding type $1,2 \mathrm{a}, 2 \mathrm{x} / \mathrm{d}$ and $2 \mathrm{~b}$ MyHC isoforms. This composition was demonstrated in both muscles by histochemical, immunocytochemical, electrophoretic and immunoblotting methods (e.g. Jaschinski et al. 1998, Stevens et al. 1999, Smerdu and Soukup 2008, Soukup et al. 2002, 2009, for review see Pette 2002).

In previous experiments, using non-real time PCR followed by densitometric evaluation of gel separated reaction products (see Hudecová et al. 2004), the presence of all four $(1,2 a, 2 x / d$ and 2b) MyHC isoform transcripts was demonstrated in the soleus muscle (Vadászová et al. 2006a), similarly as in the EDL muscle (Vadászová et al. 2006b). In order to evaluate the presence and relative quantity of $m R N A s$ for $\mathrm{MyHC}$ isoforms, we have designed a new set of primers and used them for the real time RT-PCR analysis of MyHC isoform $m R N A s$ in slow and fast hind limb rat muscles.

\section{Materials and Methods}

Animals

Female inbred Lewis strain rats were obtained from the authorized laboratory rat-breeding unit of the Institute of Physiology, Academy of Sciences, Prague, Czech Republic (Accreditation No. 1020/491/A/00). The maintenance and handling of experimental animals was in accordance with the EU Council Directive (86/609EEC) and the investigation was approved by the Expert Committee of the Institute of Physiology, Academy of Sciences, Prague, Czech Republic. Muscles were excised from four 8-month-old rats anesthetized with intraperitoneal injections of Nembutal (sodium pentobarbital $40 \mathrm{mg} / \mathrm{kg}$ ), placed in the $R N A$ stabilizing solution (Qiagen) and stored at $-80{ }^{\circ} \mathrm{C}$ until used for the real time RT-PCR. The rats were sacrificed by an overdose of the anesthetic.

\section{Primers}

The primers have been designed using the Gene Runner program (Hastings Software).

\section{$R N A$ isolation and real time RT-PCR}

Total cellular $R N A$ was extracted from each muscle sample using the RNeasy Mini kit (Qiagen). The purity and integrity of the $R N A$ preparations was checked spectroscopically and by agarose gel electrophoresis. One $\mu \mathrm{g}$ of total $R N A$ was converted to $c D N A$ using the RevertAid $^{\mathrm{TM}} \mathrm{H}$ Mius First Strand $c D N A$ Synthesis Kit (Fermentas) using oligo(dT) primers according to the manufacturer's instructions. Samples of $c D N A\left(\begin{array}{ll}1 & \mu l\end{array}\right)$ were amplified in $25 \mu \mathrm{l}$ of PCR reaction mixtures containing $\mathrm{iQ}^{\mathrm{TM}}$ SYBR Green Supermix (Bio-Rad) plus $1 \mu \mathrm{M}$ of each MyHC isoform-specific primers according to the manufacturer's instructions.

PCRs were performed on a Rotor Gene 6000 (Corbett Research) using the following temperature profile: initial denaturation at $95{ }^{\circ} \mathrm{C}$ for $2 \mathrm{~min}$, followed by 38 cycles consisting of denaturation at $95{ }^{\circ} \mathrm{C}$ for 30 sec, annealing at $54{ }^{\circ} \mathrm{C}$ for $30 \mathrm{sec}$ and elongation at $72{ }^{\circ} \mathrm{C}$ for $20 \mathrm{sec}$. Fluorescence was acquired in each cycle after heating the samples to $80{ }^{\circ} \mathrm{C}$ eliminating the noise of primer dimers (Pfaffl 2004). At the end of each run melting curve analysis was performed to ascertain the presence of a single amplicon. The data used for calculation are the means of $\mathrm{CT}$ values obtained from qPCR performed in triplicates. We have verified that the variation of triplicates did not exceed $0.5 \mathrm{CT}$. Standard 
curves were generated for each pair of primers using 3-fold serial dilution of $c D N A$. The efficiency of the PCR amplification for each primer pair was then calculated from the standard curve to precisely state the relative expression. The level of analyzed transcripts was normalized to the level of the reference gene glyceraldehyde-3-phosphate dehydrogenase (GAPDH) transcripts with regard to the specific PCR efficiency (E) for each gene as:

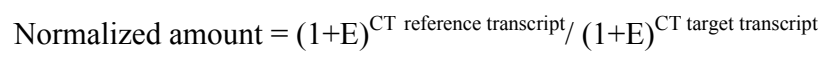

Non-template and non-RT reactions were performed as controls. The quantitative data are the means of four experiments and these are presented as ratio among values for individual $m R N A s$.

\section{Results and Discussion}

\section{Design and characterization of new primers}

We have designed a set of primers with similar melting temperatures, matching separate MyHC exons with maximal differences in MyHC coding sequences and containing $\mathrm{G}$ or $\mathrm{C}$ at the 3 'end (Fig. 1). These have also yielded PCR products of corresponding length, which is an important requirement for real time RT-PCR quantification. The primers used in our study were as follows:

MyHC1 _ F, AGAGGAAGACAGGAAGAACCTAC; MyHC1 _ R, GGCTTCACAGGCATCCTTAG; MyHC 2a F, TCCTCAGGCTTCAAGATTTG; MyHC 2a_R, TTAAATAGAATCACATGGGGAC;

MyHC 2x/d_F, AAGACCGCAAGAACGTTCTC; MyHC 2x/d_R, TCGTAAGTACAAAATGGAGTGAC;

MyHC 2b_F, GAGGACCGCAAGAACGTG; MyHC 2b_R, TGTGTGATTTCTTCTGTCACC;

\section{GAPDH F, GCTGAGTATGTCGTGGAGTC; GAPDH_R, GTCAGATCCACAACGGATAC.}

The information about the exact composition of rat $\mathrm{MyHC}$ isoforms is still incomplete in databases and often controversial, especially for the $2 b$ isoform. In our previous study (Žurmanová et al. 2007), we separated the MyHC 2b isoform by SDS-PAGE from the rat EDL muscle, identified its composition using mass spectrometry (MALDI-TOF) and sequenced it using the liquid chromatography-tandem mass spectrometry (ESI LC/MS/MS). The dataset that we obtained has allowed us to select the respective $2 \mathrm{~b} m R N A$ transcript from its alternatives present in databases and thus to design the most appropriate primers.

We used the pairs of primers and reverse transcribed $R N A$ samples isolated from both soleus and EDL muscles also in non-real time PCR and separated their respective reaction products using gel electrophoresis to ensure that only a single product is amplified in each reaction. After extraction from the gel, the DNA products were sequenced (Center of DNA Sequencing at the Institute of Microbiology, Prague) in order to check their sequence identity. Sequencing confirmed the expected lengths of PCR products; the lengths of $1,2 \mathrm{a}, 2 \mathrm{x} / \mathrm{d}$, and $2 \mathrm{~b}$ MyHC isoform PCR products were $285,309,318$, and 285 bps, respectively.

\section{Real time RT-PCR analysis}

Using the new set of primers and real time PCR technique, we have identified all four transcripts encoding MyHC 1, 2a, 2x/d and 2b isoforms both in the slow soleus and fast EDL muscles. The difference of CT values obtained from $c D N A s$ and background (corresponding $m R N A s$ or water) confirmed that both $2 \mathrm{x} / \mathrm{d}$ and $2 \mathrm{~b}$ isoform $m R N A s$ were present in the slow soleus muscle of normal adult rats (Fig. 2). In general, the relative proportion of fast $2 \mathrm{a}: 2 \mathrm{x} / \mathrm{d}: 2 \mathrm{~b}$ MyHC isoform transcripts in the soleus muscle were by two to three orders of magnitude lower than that of slow MyHC 1 isoform. This result is in agreement with the dominant content of MyHC 1 protein isoform supplemented by a small amount of MyHC 2a isoform in the adult rat soleus muscle. Our SDS-PAGE and immunohistochemical (by specific monoclonal antibodies) analyses of soleus muscle (Soukup et al. 2002, 2009) have confirmed the prevalence of the type $1 \mathrm{MyHC}$ isoform over a minority of $2 \mathrm{a}$ isoform (about 95 and $5 \%$, respectively), as well as of slow fiber type 1 over fiber type $2 \mathrm{~A}$ (97.5 and $2.5 \%$, respectively).

In the EDL muscle the relative ratio of $1: 2 \mathrm{a}$ : 2x/d : 2b MyHC isoform transcripts differed much less compared to the soleus muscle. The $2 \mathrm{~b}$ isoform $m R N A$ was roughly two orders higher compared to isoform 1 and one order of magnitude higher compared to $2 \mathrm{a}$ and $2 \mathrm{x} / \mathrm{d}$ ones. The lowest relative amount of the MyHC type 1 isoform transcript corresponds to a minor representation of about $0-5 \%$ of slow type 1 MyHC isoform (determined by SDS-PAGE) and of slow type 1 fibers 


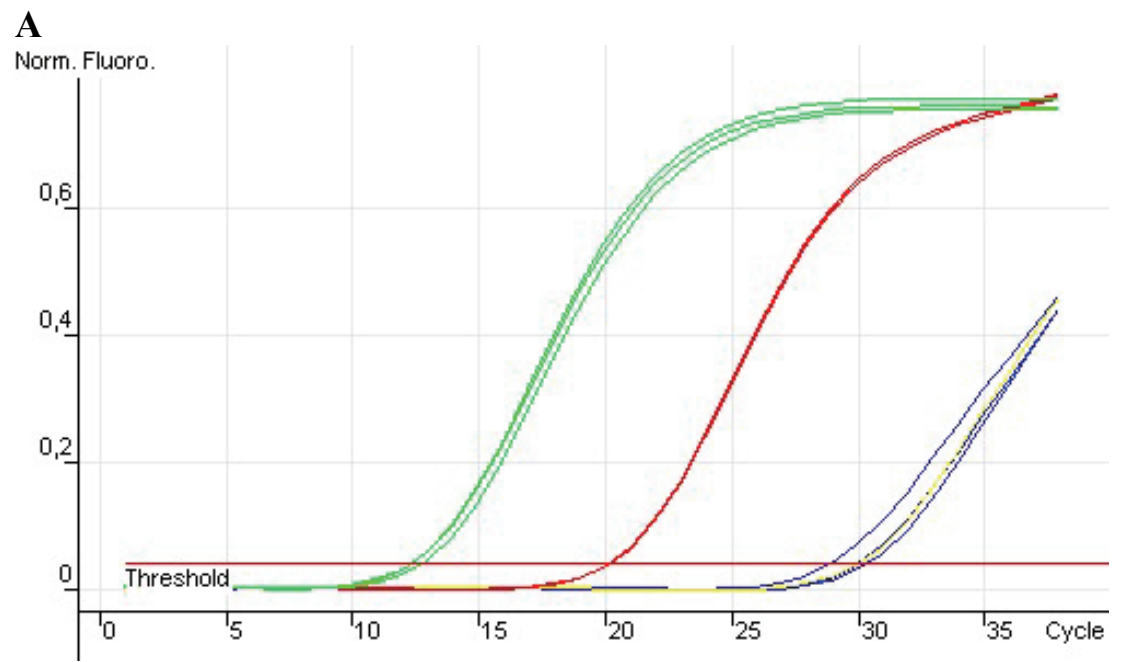

Fig. 2. The soleus muscle contains both $2 t$ and $2 x / d$ isoform mRNAs. The curves represent the fluorescent signal of GAPDH (ir green) and MyHC obtained from soleus muscle $C D N A$ (in red) or corresponding mRN/ (in blue), compared to water (in yellow) usins PCR amplification and SYBR-Green detection A, MyHC $2 x / d$; B, MyHC $2 b$.

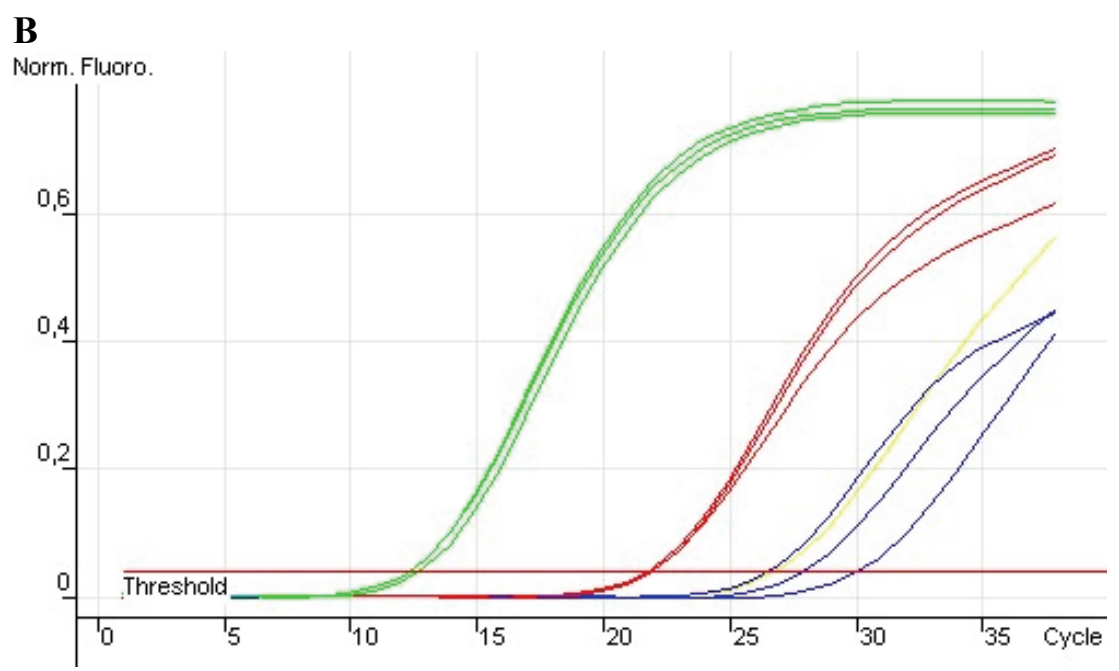

(determined by immunohistochemistry) in Lewis strain rats (Soukup et al. 2002, 2009). The amount of $m R N A s$ of fast MyHC isoforms increased in the same order as the content of MyHC protein isoforms and fiber type percentage of the adult rat EDL muscle, i.e. $2 \mathrm{a}<2 \mathrm{x} / \mathrm{d}<$ 2b (Soukup et al. 2002, 2009).

This study, together with semi-quantitative Elisa MyHC method (Říčný and Soukup, 2006) and quantitative determination of the fiber type and MyHC isoform content (Zachařová et al. 2005, VadászováSoukup et al. 2006c, Vadászová-Soukup and Soukup 2007, Soukup et al. 2009), should help us analyze the regulation of $\mathrm{MyHC}$ isoform expression in regenerating transplanted muscle in more details (for review see
Soukup and Jirmanová 2000, Vadászová et al. 2004).

\section{Conflict of Interest}

There is no conflict of interest.

\section{Acknowledgements}

The authors thank Dr. Renata Haugvicová and Dr. J. Felsberg (Center of DNA Sequencing at the Institute of Microbiology, Prague) for PCR product sequencing. The study was supported by MYORES LSH-CT-2004511978, MSMT CR LC554, GACR 304/08/0256 and $305 / 06 / 1115$ grants and by the Research projects AV0Z 50110509 and MSM 0021620858.

\section{References}

ENNION S, SANT'ANAPEREIRA AJ, SARGEANT A, YOUNG A, GOLDSPINK G: Characterization of human skeletal muscle fibers according to the myosin heavy chains they express. J Muscle Res Cell Motil 16: 35-43, 1995. 
HUDECOVÁ S, VASDÁSZOVÁ A, SOUKUP T, KRIŽANOVÁ O: Effect of thyroid hormones on the gene expression of calcium transport systems in rat muscle. Life Sci 75: 923-931, 2004.

JÄNKÄLÄ H, HARJOLA V-P, PETERSEN NE, HÄRKÖNEN M: Myosin heavy chain mRNA transform to faster isoforms in immobilized skeletal muscle: a quantitative PCR study. Appl Physiol 82: 977-982, 1997.

JASCHINSKI F, SCHULER M, PEUKER H, PETTE D: Changes in myosin heavy chain mRNA and protein isoforms of rat muscle during forced contractile activity. Am J Physiol 274: C365-C370, 1998.

JUNG HH, LIEBER RL, RYAN AF: Quantification of myosin heavy chain mRNA in somatic and branchial arch muscles using competitive PCR. Am J Physiol 275: C68-C74, 1998.

LIEBER RL, BODINE SC, BURKHOLDER TJ, PIEROTTI DJ, RYAN AF: Cloning and in situ hybridation of type-2A and type-2B rat skeletal muscle myosin tail region - implications for filament assembly. Biochem Biophys Res Commun 197: 1312-1318, 1993.

PETTE D: The adaptive potential of skeletal muscle fibers. Can J Appl Physiol 27: 423-448, 2002.

PEUKER H, PETTE D: Direct reverse transcriptase-polymerase chain reaction for determining specific mRNA expression levels in muscle fiber fragments. Anal Biochem 224: 443-446, 1995.

PEUKER H, PETTE D: Quantitative analyses of myosin heavy-chain mRNA and protein isoforms in single fibers reveal a pronounced fiber heterogeneity in normal rabbit muscles. Eur J Biochem 247: 30-36, 1997.

PFAFFL MW: Quantification strategies in real-time PCR. In: $A-Z$ of Quantitative PCR, BUSTIN SA (ed), IUL Biotechnology Series, International University Line, La Jolla, CA, 2004, pp 87-120.

Ř́IČNÝ J, SOUKUP T: Application of ELISA for myosin heavy chain isoforms quantification. Physiol. Res 55: 41P, 2006.

SAKURABA T, SHIMADA Y, TAKAHASHI S, MATSUNAGA T, ITOI E, KAWATANI M: The effect of magnetic stimulation on unloaded soleus muscle of rat: changes in myosin heavy chain mRNA isoforms. Biomed Res 26: $15-19,2005$.

SCHIAFFINO S, REGGIANI C: Molecular diversity of myofibrillar proteins: gene regulation and functional significance. Physiol Rev 76: 371-423, 1996.

SMERDU V, SOUKUP T: Demonstration of myosin heavy chain isoforms in rats and humans: the specificity of seven monoclonal antibodies used in immunohistochemical and immunoblotting methods. Eur J Histochem (Pavia) 52: 179-189, 2008.

SOUKUP T, JIRMANOVÁ I: Regulation of myosin expression in developing and regenerating extrafusal and intrafusal muscle fibres with special emphasis on the role of thyroid hormones. Physiol Res 49: 617-633, 2000.

SOUKUP T, ZACHAŘOVÁ G, SMERDU V: Fibre type composition of soleus and extensor digitorum longus muscles in normal female inbred Lewis rats. Acta Histochem 104: 399-405, 2002.

SOUKUP T, SMERDU V, ZACHAŘOVÁ G: Fiber type composition of unoperated rat soleus and extensor digitorum longus muscles after unilateral isotransplantation of a foreign muscle in long-term experiments. Physiol Res 58: in press, 2009.

STEVENS L, GOHLSCH B, MOUNIER Y, PETTE D: Changes in myosin heavy chain mRNA and protein isoforms in single fibers of unloaded rat soleus muscle. FEBS Letts 463: 15-18, 1999.

VADÁSZOVÁ A, ZACHAŘOVÁ G, MACHÁČOVÁ K, JIRMANOVÁ I, SOUKUP T: Influence of thyroid status on the differentiation of slow and fast rat muscle phenotypes. Physiol Res 53 (Suppl 1): S57-S61, 2004.

VADÁSZOVÁ A, HUDECOVÁ S, KRIŽANOVÁ O, SOUKUP T: Levels of myosin heavy chain mRNA transcripts and content of protein isoforms in the slow soleus muscle of 7-month-old rats with altered thyroid status. Physiol Res 55: 221-225, 2006a.

VADÁSZOVÁ A, HUDECOVÁ S, KRIŽANOVÁ O, SOUKUP T: Levels of myosin heavy chain mRNA transcripts and protein isoforms in the fast extensor digitorum longus muscle of 7-month-old rats with chronic thyroid status alterations. Physiol Res 55: 707-710, $2006 \mathrm{~b}$.

VADÁSZOVÁ-SOUKUP A, SMERDU V, ŽURMANOVÁ J, MALÁČOVÁ D, SOUKUP T: Unilateral foreign muscle transplantation has no effect on phenotype of unoperated rat muscles in long term experiments. Physiol Res $\mathbf{5 5}$ : 49P, 2006c.

VADÁSZOVÁ-SOUKUP A, SOUKUP T: Dual role of thyroid hormones in rat soleus muscle MyHC isoform expression. Physiol Res 56: 833-836, 2007. 
WRIGHT C, HADDAD F, QIN AX, BALDWIN KM: Analysis of myosin heavy chain mRNA expression by RT-PCR. J Appl Physiol 83: 1389-1396, 1997.

ZACHAŘOVÁ G, VADÁSZOVÁ A, SMERDU V, ASMUSSEN G, SOUKUP T: The effect of a unilateral muscle transplantation on the muscle fiber type and the MyHC isoform content in unoperated hind limb slow and fast muscles of the inbred Lewis rats. Physiol Res 54: 691-696, 2005.

ŽURMANOVÁ J, MALÁČOVÁ D, PUTA F, NOVÁK P, ŘÍČNÝ J, SOUKUP T: Mass spectrometry analyses of rat 2b myosin heavy chain isoform. Physiol Res 56: 659-662, 2007. 